\title{
Foreword and Acknowledgments
}

Place Branding and Public Diplomacy (2007) 3, 1. doi:10.1057/palgrave.pb.6000052

This special issue of Place Branding and Public Diplomacy on 'The Challenge of Place Branding in Emerging, Transitional, Negatively Viewed and Newly Industrialised Nations' received a large number of submissions, contemplating places in very different corners of the world, such as Asia, Europe and Latin America. Such a positive response to the call for papers indicates the relevance and interest on the topic, something that we hope will continue to receive attention from this and other publications.

Even though most submissions had merits and presented interesting views and experiences, it was not possible to include all of them in this issue. We would like to acknowledge the scholars and branding experts who kindly agreed to review the numerous submissions and shared their insights, opinions and advice with the contributors. They are in alphabetical order Simon Anholt, József Beracs, Larry Bridwell, João Freire, James Gould,
Leo Gertner, Rosane Gertner, Dennis Guthery, Carl Malinowski, Roy Nelson, David O'Donovan, Randi Priluck and Kathy Winsted.

Lastly, I would like to thank the editor of Place Branding and Public Diplomacy, Simon Anholt, for the invitation to serve as the special editor for this issue and for supporting the topic I proposed for it. I am also thankful for the incredible support and assistance provided to me by Brenda Rouse, Publishing Manager of Place Branding and Public Diplomacy. This has been a great and rewarding learning experience. I hope Place Branding and Public Diplomacy readers find some interesting material among the conceptual articles, case studies and research reports included in this issue.

David Gertner
Associate Professor of Marketing
Lubin School of Business,
Pace University, NY, USA

